\title{
Estramustine-Paclitaxel Regimen
}

National Cancer Institute

\section{Source}

National Cancer Institute. Estramustine-Paclitaxel Regimen. NCI Thesaurus. Code C64843.

A reg imen consisting of estramustine and paclitaxel used for the treatment of hormonerefractory prostate cancer. 